\title{
Ephrin-B2 and EphB2 Regulation of Astrocyte-Meningeal Fibroblast Interactions in Response to Spinal Cord Lesions in Adult Rats
}

\author{
Liza Q. Bundesen, Tracy Aber Scheel, Barbara S. Bregman, and Lawrence F. Kromer \\ Department of Neuroscience, Georgetown University Medical Center, Washington, DC 20057
}

\begin{abstract}
The present study provides the first evidence that signaling occurs between B-ephrins and EphB receptors in the adult CNS in response to injury. Specifically, our combined histological and biochemical data indicate that two members of the B-class of ephrins and Eph receptors, ephrin-B2 and EphB2, are expressed by astrocytes and meningeal fibroblasts, respectively, in the adult spinal cord. In response to thoracic spinal cord transection lesions, ephrin-B2 and EphB2 protein levels exhibit an initial decrease ( $1 \mathrm{~d}$ after lesion), followed by a significant increase by day 14 . Immunohistochemical data indicate that ephrin-B2 is expressed by reactive CNS astrocytes, and EphB2 is present on fibroblasts invading the lesion site from the adjacent meninges. During the first $3 \mathrm{~d}$ after injury, there is intermingling of ephrin-B2-expressing reactive astrocytes at the lesion surface with EphB2-containing fibroblasts that is concurrent with bidirectional activation (phosphorylation) of ephrin-B2 and EphB2. By $7 \mathrm{~d}$, both cell types are establishing restricted cellular domains containing dense networks of cells and interweaving processes. This astroglial-meningeal fibroblast scar is fully developed by day 14 when there is strict segregation of ephrin-B2-expressing astrocytes from EphB2-positive meningeal fibroblasts. These morphological changes are concomitant with a simultaneous decrease in ephrin-B2 and EphB2 activation. These observations provide strong evidence that cell contactmediated bidirectional signaling between ephrin-B2 on reactive astrocytes and EphB2 on meningeal fibroblasts is an early event in the cellular cascades that result in the development of the glial scar and the exclusion of meningeal fibroblasts from the injured spinal cord.
\end{abstract}

Key words: ephrin; EphB; receptor tyrosine kinase; glial scar; astrocyte; fibroblast; spinal cord injury; reactive gliosis; rat

\section{Introduction}

After penetrating injuries to the adult CNS, a number of cellular responses occur that are necessary to reestablish CNS integrity and homeostatic function. One response is reactive gliosis, during which astrocytes proliferate and produce a network of interweaving processes that form a glial scar and provide a barrier against additional invasion by meningeal fibroblasts (Berry et al., 1983; Eng et al., 1987; Reier and Houle, 1988). Along this glialfibroblast interface, both astrocytes and meningeal cells participate in producing a new basal lamina (Abnet et al., 1991; Sievers et al., 1994) that, in combination with the glial end feet, reforms the glia limitans (Peters et al., 1976). This process is believed to be essential for restoring the blood-brain barrier and reestablishing CNS homeostasis (for review, see Reier et al., 1986). The molecular mechanisms responsible for regulating the formation of this glial-meningeal boundary are primarily unknown. Thus, we chose to examine the possible involvement of the Eph family of

Received Nov. 14, 2002; revised June 10, 2003; accepted June 10, 2003.

This research was supported by the International Spinal Research Trust, the Daniel Heumann Fund for Spinal Cord Research, and by National Institutes of Health Grants T32 HD 07459, T32 NS41218, and NS 19259. Anti-EphB2 antibodies were generously provided by Elena Pasquale. We thank Haining Dai for his assistance with surgeries and Scott Janis for his help during the inception of this study. We thank Robert Yasuda for his advice on the Western blot analysis and data quantification.

Correspondence should be addressed to Dr. Lawrence F. Kromer, Department of Neuroscience, Georgetown University Medical Center, EP02, Research Building, 3970 Reservoir Road, N.W., Washington, DC 20057. E-mail: kromerl@georgetown.edu.

Copyright $\odot 2003$ Society for Neuroscience $\quad 0270-6474 / 03 / 237789-12 \$ 15.00 / 0$ receptor tyrosine kinases and their ligands, the ephrins, in glial scar formation because cell-cell signaling through these molecules regulates multiple aspects of cell migration and compartment formation during development (for review, see Flanagan and Vanderhaeghen, 1998; Wilkinson, 2000, 2001).

Ephrins and Eph receptors are divided into two subclasses on the basis of their sequence homologies and binding specificities (Flanagan and Vanderhaeghen, 1998; Wilkinson, 2000, 2001). Ephrin-A ligands (ephrin-A1-ephrin-A6) are associated with the plasma membrane via a glycosyl phosphatidylinositol linkage (Zhou, 1998; Menzel et al., 2001) and preferentially bind the EphA subclass of receptors (EphA1-EphA8) (Gale et al., 1996; Janis et al., 1999; Menzel et al., 2001), whereas ephrin-B ligands (ephrin-B1-ephrin-B3) are transmembrane glycoproteins that preferentially interact with members of the EphB receptor subclass (EphB1-EphB6) (Gale et al., 1996). Ephrins must be bound to the cell membrane for signaling to occur, suggesting that functional receptor-ligand interactions require cell-cell contact (Davis et al., 1994; Holland et al., 1996; Bruckner et al., 1997; Stein et al., 1998). Several studies indicate that bidirectional signaling occurs between EphB receptors and B-ephrins, leading to intracellular signaling cascades in both the receptor and ligandbearing cells (Holland et al., 1996; Bruckner et al., 1997, 1999; Mellitzer et al., 1999; Kalo et al., 2001; Cowan and Henkemeyer, 2002).

During development, Eph receptors and ephrins play diverse 
roles in tissue patterning, cell migration, and axon guidance. Ephrins and Eph receptors can function as contact-mediated repellants, preventing cells that express complementary ligands and receptors from entering inappropriate territories. This function is well documented during formation of hindbrain rhombomeres, in which bidirectional Eph-ephrin signaling at the interface of rhombomere domains is necessary to restrict cell intermingling across rhombomere boundaries (Mellitzer et al., 1999; Xu et al., 1999; Wilkinson, 2000, 2001). The B-family of Eph receptors and ephrins also participates in the segmental organization of spinal nerves. Early-migrating EphB2-expressing neural crest cells are repelled by ephrin-B ligands (ephrin-B1 in chick and ephrin-B2 in rat) expressed in the caudal somitic compartment (Krull et al., 1997; Wang and Anderson, 1997), resulting in the segmental organization of the dorsal roots as they join to form the spinal nerve. Based on the role of B-ephrins and EphB receptors in early spinal cord development, we hypothesized that EphB2 and ephrin-B2 may be present in the adult spinal cord in which they could regulate cellular responses to injury. Here, we report that, after a spinal cord lesion in the adult rat, reactive astrocytes express ephrin-B2, and infiltrating meningeal fibroblasts express EphB2 at the lesion interface. Moreover, both ephrin-B2 and EphB2 are transiently phosphorylated in conjunction with the development of restricted glial and fibroblast domains along the lesion interface.

\section{Materials and Methods}

Animals and thoracic transection surgery. Adult female Sprague Dawley rats (200-250 gm body weight) were obtained from Zivic Laboratories (Allison Park, PA). Animals were housed, cared for, and used strictly in accordance with United States Department of Agriculture regulations and the National Institutes of Health Guide for the Care and Use of Laboratory Animals (publication number 85-23, 1985). The Georgetown University Division of Comparative Medicine is fully accredited by the American Association for the Accreditation of Laboratory Animal Care. Rats received complete spinal cord transections at the T6-T8 spinal levels using methods described previously (Coumans et al., 2001). Animals were anesthetized with chloral hydrate $(400 \mathrm{mg} / \mathrm{kg}$ body weight, i.p.). After laminectomy, the dura was opened, and the spinal cord was transected using iridectomy scissors. Vacuum suction was used to clear the most lateral recesses of the canal. The severed ends of the cord were inspected under a surgical microscope to ensure complete transection. A $1 \mathrm{~mm}$ cubic piece of Gelfoam (Amersham Biosciences, Arlington Heights, IL; Upjohn Company, Kalamazoo, MI) was placed in the cavity to assist in hemostasis. The overlying layers of muscle were closed with sutures, and the skin was closed with wound staples. After surgery, bladders were manually expressed twice per day or as necessary. Operates received sulfamethoxazole $(4 \mathrm{mg} / 100 \mathrm{gm})$ and trimethoprim $(0.8 \mathrm{mg} /$ $100 \mathrm{gm})$ twice per day orally to prevent infection. Animal weight and hydration were carefully monitored. If dehydrated, animals received subcutaneous injections of D5-lactated Ringer's solution. Food was provided on the cage floor, and the rats had no difficulty reaching their water bottles. Supplemental oral feedings of STAT hypercaloric formula (Pegasus Laboratories, Pensacola, FL) were given as necessary. Animals were killed at $1,3,7,10$, and $14 \mathrm{~d}$ after transection surgery.

Tissue processing. For immunohistochemical examination, rats were anesthetized with an overdose of chloral hydrate $(10 \mathrm{mg} / \mathrm{kg}$ body weight $)$ and perfused intracardially with $4 \%$ paraformaldehyde in $0.1 \mathrm{~m}$ phosphate buffer, $\mathrm{pH}$ 7.4. After perfusion, the spinal cord was removed, postfixed for 1 $\mathrm{hr}$ in $4 \%$ buffered paraformaldehyde $\left(4^{\circ} \mathrm{C}\right)$, and then cryoprotected in $30 \%$ sucrose. Serial cryosections of spinal cord $(20 \mu \mathrm{m})$ were cut in a coronal or longitudinal plane and thaw mounted onto Super Frost Plus slides (Fisher Scientific, Springfield, NJ). For Western blot analysis, animals were perfused intracardially with ice-cold saline $(0.9 \%)$ to remove the blood and rapidly chill the spinal cord tissue. After exsanguination, the fresh spinal cord tissue was quickly dissected, immediately frozen on dry ice, and stored at $-80^{\circ} \mathrm{C}$.
The lesion area was carefully measured to include $3 \mathrm{~mm}$ of tissue immediately rostral and caudal to the lesion epicenter. Care was taken to not include the dorsal root ganglia (DRGs) in the sample.

Antibody specificity. Because of concerns regarding potential antibody cross-reactivity, many controls were performed to ensure that the ephrin-B2 and EphB2 antibodies were specific to their target proteins. Affinity-purified EphB2 antibody was obtained from Elena Pasquale (Burnham Institute, La Jolla, CA). Although the specificity of this antibody has been documented in several publications (Karam et al., 2000; Koblar et al., 2000; Cramer et al., 2002), the specificity of this antibody was additionally tested on Western blots of cortical tissue from EphB2 ${ }^{-1-}$ mice (Mark Henkemeyer, University of Texas Southwestern Medical Center, Dallas, TX). The analysis confirmed that this EphB2 antibody did not immunoprecipitate or recognize any proteins in the EphB2 ${ }^{-1-}$ mice. Additional affinity-purified ephrin-B2 and EphB2 antibodies were obtained from R \& D Systems (Minneapolis, MN). Specificity tests on Western blots containing a panel of EphB or ephrin-B fusion proteins indicated that there was some cross-reactivity of both antibodies to other members of this family of proteins. To eliminate this cross-reactivity, the antibodies were preabsorbed with cross-reacting EphB or ephrin-B fusion proteins. Briefly, $100 \mu \mathrm{g}$ of EphB or ephrin-B fusion protein (R \& D Systems) at a concentration of $1 \mu \mathrm{g} / \mu \mathrm{l}$ was bound to Protein-A agarose beads (Roche Diagnostics, Mannheim, Germany) using $100 \mathrm{~mm}$ sodium borate, $\mathrm{pH}$ 8. Fusion proteins and Protein-A were cross-linked by incubating them in $20 \mathrm{~mm}$ dimethyl pimelimidate (Pierce, Rockford, IL) in $100 \mathrm{~mm}$ sodium borate, $\mathrm{pH}$ 9, for $30 \mathrm{~min}$ at room temperature. The fusion protein-Protein-A complex was incubated with $0.2 \mathrm{M}$ ethanolamine for $2 \mathrm{hr}$ at room temperature to block unbound sites on the Protein-A beads, washed twice in IgG elution buffer (Pierce) and four times in $100 \mathrm{~mm}$ sodium borate, $\mathrm{pH} 8$, and then resuspended in $0.1 \mathrm{M}$ PBS to produce a $50 \%$ slurry. Before use in experiments, the ephrin-B2 antibody was incubated with a twofold concentration of ephrin-B1-Protein-A, and the EphB2 antibody was incubated with twofold concentrations of EphB1-Protein-A and EphB3-Protein-A overnight at $4^{\circ} \mathrm{C}$. Western blots confirmed that the preabsorbed ephrin-B2 antibody did not cross-react with ephrin-B1 or ephrin-B3, and that preabsorbed EphB2 antibody did not cross-react with EphB1, EphB3, EphB4, or EphB6. EphB5 was not examined because it is not expressed in rodents (Sajjadi and Pasquale, 1993; Soans et al., 1996).

Immunohistochemistry. Immunohistochemistry was performed on paraformaldehyde-fixed tissue cut in $20-\mu \mathrm{m}$-thick serial coronal or horizontal sections mounted on Superfrost Plus slides (Fisher Scientific). Tissue was washed in three rinses of $0.1 \mathrm{M}$ PBS for $5 \mathrm{~min}$ each and blocked in $0.2 \%$ Triton X-100-PBS and 10\% normal donkey serum for $1 \mathrm{hr}$ at room temperature. Tissue was incubated with primary antibodies in $0.2 \%$ Triton X-100-PBS and $2 \%$ normal donkey serum overnight at $4^{\circ} \mathrm{C}$. Goat anti-ephrin-B2 antibody (R \& D Systems) was used at a concentration of $3 \mu \mathrm{g} / \mathrm{ml}$. Rabbit anti-EphB2 antibody (courtesy of Elena Pasquale) was used at a concentration of $5 \mu \mathrm{g} / \mathrm{ml}$. To colocalize ephrin-B2 and EphB2 with specific cell types, the following primary antibodies were used: mouse anti-glial fibrillary acidic protein (GFAP) (1:200; Sigma, St. Louis, MO) and rabbit anti-GFAP (1:10; Dako, Carpinteria, CA) to identify astrocytes; mouse $\mathrm{CC} 1$ antibody against allophycocyanin (APC) to identify oligodendrocytes (1:1000; Oncogene, San Diego, CA); mouse anti-vimentin (1:20; Chemicon, Temecula, CA) and mouse antifibronectin (1:100; Sigma) to identify fibroblasts; mouse anti-neuronal nuclear protein $(\mathrm{NeuN})$ to identify neurons (1:100; Chemicon); and mouse OX42 antibody (1:100; Serotec, Raleigh, NC) to identify macrophages and microglia. For single antigen staining, biotinylated donkey secondary antibodies were incubated with tissue for $1 \mathrm{hr}$ at room temperature (1:200; Jackson ImmunoResearch, West Grove, PA). The immunolabeling was visualized using the Vector ABC (avidin-biotinylated enzyme complex) peroxidase reaction. Tissue was examined with an Olympus Optical (Tokyo, Japan) BX51 microscope with SPOT RT software (version 3.2; Diagnostic Instruments, Sterling Heights, MI). For double-label immunohistochemistry, donkey secondary antibodies conjugated to FITC or Texas Red were incubated with tissue for $1 \mathrm{hr}$ at room temperature (1:200; Jackson ImmunoResearch). Fluorescent staining was analyzed using an Olympus Optical BX51 fluorescent microscope 
with SPOT RT software or an Olympus Optical 1X70 inverted confocal laser scanning microscope with Olympus Optical Fluoview software (version 2.0).

Protein determinations. To quantify temporal changes in protein levels that occur after spinal cord lesions, we used protein precipitation procedures in conjunction with Western blots to detect protein bands with the Pierce SuperSignal West Pico chemiluminescent detection procedure. In the present experiments, three types of protein measurements were performed on the same spinal cord tissue sample to minimize the number of lesioned animals needed to obtain data for protein and phosphorylation levels of ephrin-B2 and EphB2 at each postlesion survival time. To accomplish this, we used sequential precipitation procedures on tissue samples that were lysed in ice-cold $\left(4^{\circ} \mathrm{C}\right)$ lysis buffer [ $50 \mathrm{~mm}$ Tris, $\mathrm{pH} 7.5$, containing $150 \mathrm{~mm} \mathrm{NaCl}, 1 \%$ Triton X-100, 0.5\% deoxycholate, $0.1 \%$ SDS, $0.2 \mathrm{~mm}$ EDTA, $10 \mathrm{~mm} \mathrm{NaF}, 10 \mu \mathrm{g} / \mathrm{ml}$ aprotinin, $1 \mu \mathrm{g} / \mathrm{ml}$ leupeptin, $10 \mu \mathrm{g} / \mathrm{ml}$ pepstatin, $0.4 \mathrm{~mm}$ 4-(2-aminoethyl)-benzenesulfonyl fluoride, and $1 \mathrm{~mm}$ sodium orthovanadate]. The protein concentration of the lysates was estimated using the method of Bradford (with reagents from Bio-Rad, Hercules, CA), and the total protein content between samples was equalized. Initially, EphB2 was immunoprecipitated from $1 \mathrm{mg}$ total protein/ml tissue lysate using a goat antibody directed against the extracellular domain of EphB2 (R \& D Systems). After overnight incubation and subsequent precipitation of the EphB2-antibody complex with Protein G-Agarose (Roche Diagnostics), we removed a $900 \mu \mathrm{l}$ aliquot of lysate, added wheat germ agglutinin (WGA) linked to agarose (50 $\mu \mathrm{l}$ of $50 \%$ slurry; $5 \mathrm{mg} / \mathrm{ml}$ binding capacity; Sigma), and incubated the aliquot at $4^{\circ} \mathrm{C}$ overnight to bind the remaining glycosylated proteins. This second procedure proved highly reliable and sensitive for removing ephrin-B2 from the spinal cord lysates. The precipitated protein complexes were washed in three changes of cold $\left(4^{\circ} \mathrm{C}\right)$ lysis buffer. EphB2 and ephrin-B2 proteins were dissociated by heating at $100^{\circ} \mathrm{C}$ for $5 \mathrm{~min}$ in sample buffer (2\% SDS, 100 mm DTT, 10\% glycerol, and $0.02 \%$ bromophenol blue) before loading on 7.5 or $10 \%$ SDS polyacrylamide gels to resolve protein bands. After transfer to nitrocellulose filters, the filters were blocked with $2 \%$ bovine serum albumin (BSA) in $0.1 \mathrm{M}$ PBS and then incubated overnight at $4^{\circ} \mathrm{C}$ with the appropriate primary antibody. The filters were developed using SuperSignal West Pico chemiluminescence reagents (Pierce) with secondary antibodies from Boehringer Mannheim (Indianapolis, IN).

The sequential use of antibody to concentrate EphB2 and WGA to concentrate ephrin-B2 proteins provided complimentary techniques that permitted maximum sensitivity for detecting both proteins. Western blots containing precipitated EphB2 were first immunostained with a monoclonal antibody specific for phosphorylated tyrosine $(1 \mu \mathrm{g} / \mathrm{ml}$ 4G10; Upstate Biotechnology, Lake Placid, NY) to detect activated EphB2 receptors. These blots were stripped and reprobed with antibodies against the EphB2 receptor ( $100 \mathrm{ng} / \mathrm{ml}$; R \& D Systems). To strip, blots were rinsed in distilled water and incubated with strip buffer (2\% SDS, $100 \mathrm{~mm} 2$-mercaptoethanol, and $62.5 \mathrm{~mm}$ Tris, $\mathrm{pH}$ 6.8) for $30 \mathrm{~min}$ at $60^{\circ} \mathrm{C}$. Blots were rinsed in distilled water, washed in TBS, and blocked with BSA before reprobing. Blots containing glycoproteins precipitated with WGA were immunostained with an ephrin-B2 antibody $(100 \mathrm{ng} / \mathrm{ml}$; R \& D Systems) to selectively identify this protein. Because it was not possible to determine whether ephrin-B2 was specifically phosphorylated using this procedure, a second group of samples were lysed as above and immunoprecipitated with ephrin-B2 antibodies (R \& D Systems) cross-linked to Protein-G beads. The resulting blots were probed either with a phosphotyrosine antibody (PY-20; BD Biosciences, San Jose, CA) or with an antibody that specifically recognized tyrosine 324/329 phosphorylated B-ephrins (1:1250; Cell Signaling Technology, Beverly, MA).

The amount of phosphorylated and total ephrin-B2 and EphB2 in the protein bands was calculated on the basis of the integrated intensity of each band as described previously (Wang et al., 1995). The integrated intensities of the protein bands on the Western blots were measured using Bio Image Systems (Jackson, MI) Intelligent Quantifier software (version 3.0). Density values in Western blots are influenced by a number of factors that fluctuate from day to day, including pipetting errors, antibody binding strength, chemiluminescence intensity, and chemical film development. To reduce the effect of these uncontrollable perturba- tions, we performed a normalization procedure on the observed density values. Because individual assays contain lanes with samples from uninjured spinal cord and each of the different postlesion time points, these individual blots should contain the same amount of total protein. We therefore expressed the integrated intensities as a ratio relative to the total average integrated intensity for all lanes run on a given blot. Although absolute density values vary between blots, the ratio of the integrated intensity of a particular protein band to the total average integrated intensity detected on that blot remains much more consistent. Because the objective of our protein measurement experiments was to identify possible temporal changes in EphB2 and ephrin-B2 levels in response to spinal cord lesions, we then expressed this data relative to integrated intensities of EphB2 and ephrin-B2 proteins in the uninjured spinal cord. GraphPad Prism software (version 3.02; GraphPad Software, San Diego, CA) was used to perform multivariate statistical analysis in conjunction with a Tukey's multiple comparison test to assess the significance of differences between experimental groups.

Because there were concomitant changes in both protein levels and phosphorylation states of EphB2 and ephrin-B2, we developed a phosphorylation index for each lesion time point to further control for the possible effects that increased protein levels of EphB2 and ephrin-B2 have on the relative phosphorylation states of these molecules compared with control levels. This phosphorylation index was based on the level of phosphorylated EphB2 and ephrin-B2 protein relative to the average total EphB2 and ephrin-B2 protein present at each time (compared with control values). In uninjured control samples, the phosphorylation index was set as one (100\% of control phosphorylation levels divided by $100 \%$ of total control protein). Similarly, the phosphorylation level (percentage of control) for each postinjury time point was divided by the average percentage of protein level relative to control for each time point. This method permitted us to approximate the fold change in EphB2 and ephrin-B2 phosphorylation relative to total protein and to compare this relative phosphorylation state at each survival time with uninjured control levels.

\section{Results}

\section{Ephrin-B2 and EphB2 expression in the adult spinal cord}

Although ephrin-B2 and EphB2 are expressed during spinal cord and spinal nerve development (Krull et al., 1997; Wang and Anderson, 1997; Koblar et al., 2000), the persistence of these proteins in the adult spinal cord has not been documented. Thus, we used immunohistochemical procedures to determine whether ephrin-B2 or EphB2 was present in the adult spinal cord. Thoracic spinal cord tissue sections from adult rats were incubated with affinity-purified ephrin-B2 or EphB2 antibodies, which were preabsorbed against other members of the B-family of ephrins and Eph receptors to eliminate possible cross-reactivity (see Materials and Methods). Specific cell populations were detected with double-label immunofluorescence using the following antibodies: anti-neuronal nuclear protein to identify neurons, CC1 antibody against APC to identify oligodendrocytes, anti-vimentin and anti-fibronectin to identify fibroblasts, antiGFAP to identify astrocytes, and OX42 antibody to identify macrophages and microglia.

Double-label immunostaining for ephrin-B2 and GFAP demonstrated that astrocytes in both the gray and white matter of the adult spinal cord expressed ephrin-B2, although white matter astrocytes were much more strongly immunoreactive than those in the gray matter (Fig. $1 A-D$ ). All gray matter astrocytes were immunoreactive for ephrin-B2; thus, the weak immunostaining observed was likely attributable to limited expression of the ligand by each cell rather than expression by a subpopulation of gray matter astrocytes. Both types of astrocytes possessed ephrinB2-positive glial end feet that were in contact with blood vessels (Fig. 1E). In addition, ephrin-B2-positive glial end feet were closely associated with the pial surface of the spinal cord (Fig. $1 F)$. 
The close apposition of ephrin-B2positive astrocytic processes to blood vessels and the meningeal coverings suggested that cells in these structures might possess a complementary EphB receptor.

Because EphB2 is expressed in the developing DRG and spinal cord, we used immunohistochemical procedures to identify whether EphB2 receptor protein was present in the adult spinal cord or in the associated blood vessels, meninges, or DRG. Histological sections of the spinal cord were immunostained with two different EphB2-specific antibodies to ensure accurate localization of this receptor. Both antibodies demonstrated immunostaining in laminas I-III of the dorsal horn (Fig. $2 A)$ and on small- and medium-sized DRG neurons but not large-diameter neurons (Fig. 2B). This finding is consistent with reports that EphB2 is present on migrating neural crest cells during spinal cord development and indicates that a subpopulation of these cells maintain expression of EphB2 on their perikarya and afferent axons in the dorsal horn of the adult spinal cord. In addition, EphB2 was strongly expressed by fibroblasts in the meningeal covering of the spinal cord (Fig. $2 C-F$ ) but was not observed in vascular cells. This observation suggests that blood vessels in the adult may express a different member of the EphB receptor family. One likely candidate is EphB4, which is present on vascular endothelial cells during development and is required for angiogenesis (Wang et al., 1998; Gerety et al., 1999). The contact observed between EphB2-positive meningeal fibroblasts and ephrin-B2positive astrocytes suggested that this com-
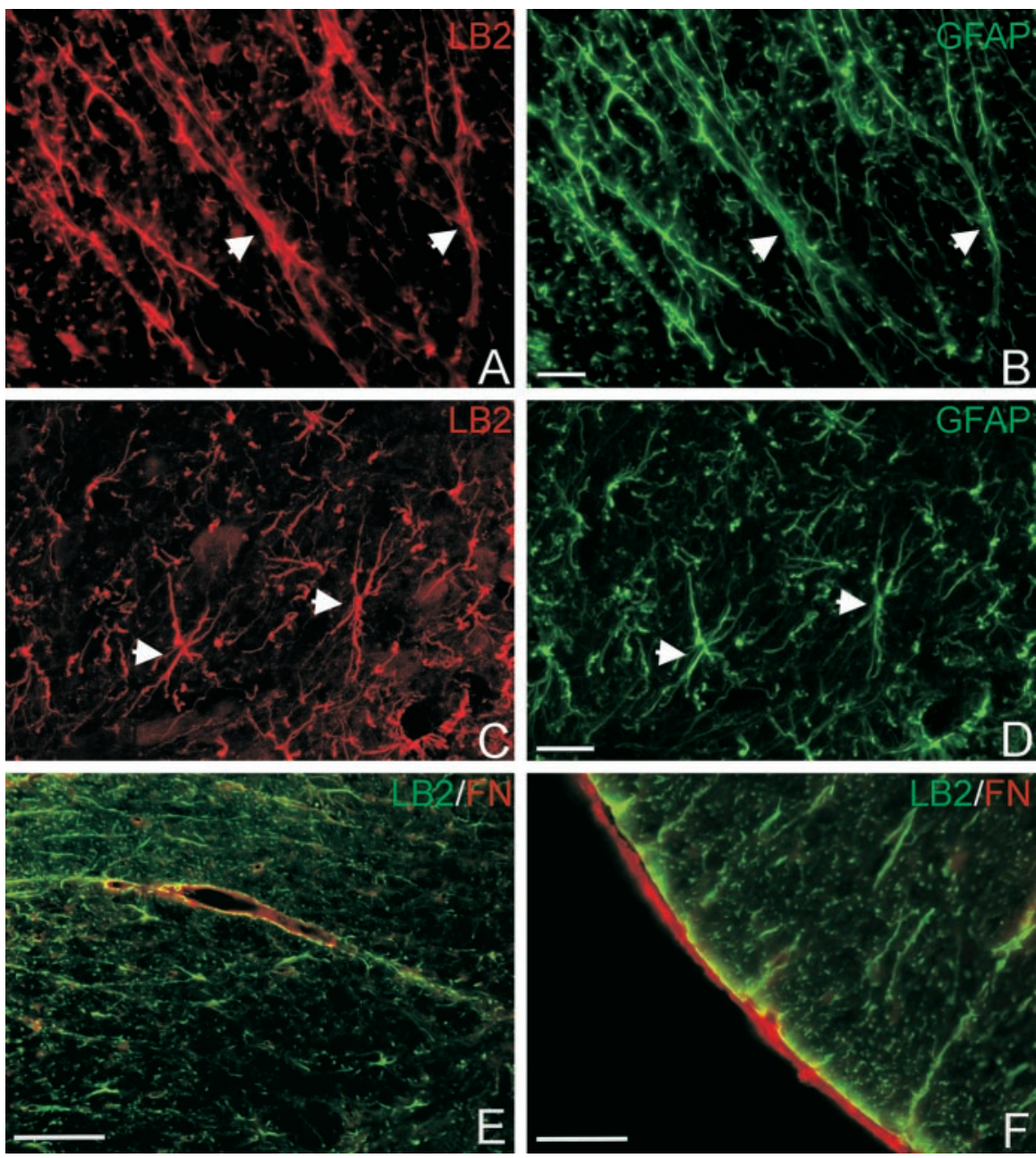

Figure 1. Ephrin-B2 ligand immunohistochemistry in the uninjured adult spinal cord. Ephrin-B2 (LB2; red) is expressed by white matter $(A)$ and gray matter $(C$ astrocytes, as confirmed by GFAP double labeling (green; $B, D)$. Arrowheads mark some double-stained cells. E, F, Ephrin-B2-positive glial end feet (LB2; green) contact fibronectin-positive blood vessels (FN; red) in the white matter $(E)$ and the fibronectin-positive pial fibroblasts (red) on the surface of the spinal cord ( $F$ ). Scale bars: $A-D, 20 \mu \mathrm{m}$; $E, F, 50 \mu \mathrm{m}$

plementary receptor-ligand pairing might play a role in glial-meningeal interactions in the mature CNS.

\section{Temporal analysis of ephrin-B2 and EphB2 protein changes after spinal cord lesions}

To evaluate the potential involvement of ephrin-B2 and EphB2 in glial scar development and the reformation of the glial-limiting membrane after spinal cord injury, we used a thoracic spinal cord lesion model combined with Western blot analysis. This approach allowed us to examine changes in ephrin-B2 and EphB2 protein levels and phosphorylation states during acute stages of the spinal cord injury response when the glial scar and the glialmeningeal barrier are forming. For these experiments, complete thoracic spinal cord transections (at level T7) were made in adult female Sprague Dawley rats. Animals were permitted to survive for $1,3,7,10$, and $14 \mathrm{~d}$ after lesion. After the rats were killed, the lesion epicenter plus spinal cord tissue $3 \mathrm{~mm}$ rostral and caudal to the lesion cavity were collected for quantification of ephrin-B2 and EphB2 protein levels. This area encompassed tissue receiving the greatest local damage from the injury and included areas containing astrogliosis, fibroblast infiltration, vascular reactivity, and microglia and macrophage activation. Tissue from this lesion area was lysed, and total protein was extracted and equalized between samples for Western blot analysis.

To determine the effect of spinal cord injury on ephrin-B2 protein levels over time, wheat germ agglutinin precipitation was used to concentrate glycosylated ephrin-B2 protein from the tissue lysates. The resulting Western blots were probed with ephrin-B2 antibody to determine protein levels in each sample. During the initial periods after injury, ephrin-B2 protein decreased compared with uninjured controls but rebounded back to and above control levels at later postinjury time points (Fig. $3 A$, top). To quantify temporal changes in ephrin-B2 protein, four to five lesioned animals were evaluated at each survival time. One-way ANOVA revealed a significant difference between groups $(p<0.0001)$. At $1 \mathrm{~d}$ after injury, there was a rapid decrease in ephrin-B2 of $\sim 66 \%$ from uninjured control levels. However, the level of ephrin-B2 quickly rebounded to near control levels by $3 \mathrm{~d}$ and exhibited a significant increase $(p<0.05)$ of $76-$ $84 \%$ above uninjured levels from 7 to $14 \mathrm{~d}$ after lesion (Fig. 3B).

To determine whether the observed changes in ephrin-B2 protein levels coincided with changes in the activation state, we detected phosphorylated ephrin-B2 in blots of immunoprecipitated ephrin-B2 that were probed with either a phosphotyrosine antibody or an antibody specific for phosphorylated B-ephrins 

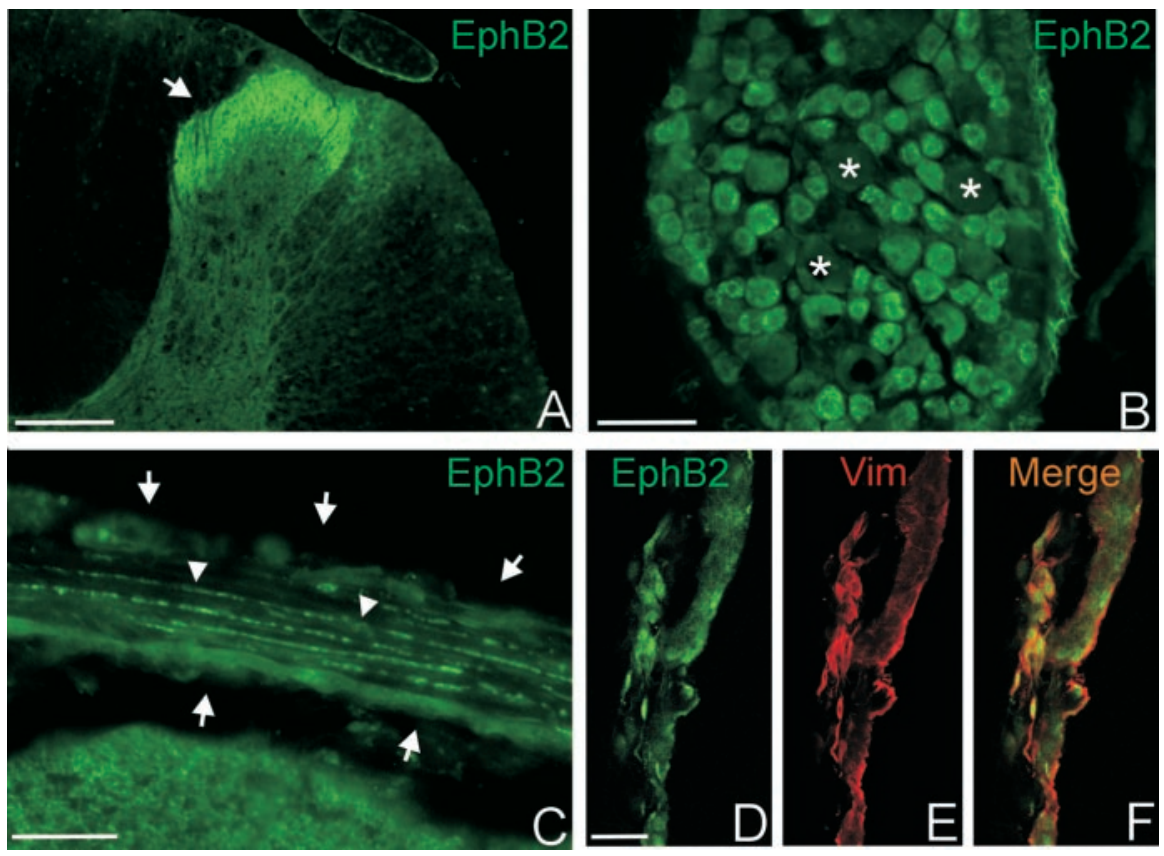

0.23 SEM $)$, and $14 \mathrm{~d}(1.72 \pm 0.48 \mathrm{SEM})$ after injury were not significantly different from control levels $(p>0.05)$. Thus, phosphorylation of ephrin-B2 was a rapid and transient event, occurring during the first few days after injury.

Temporal changes in EphB2 protein also were detected after spinal cord lesions (Fig. 3D, top) (one-way ANOVA; < 0.0001). As for ephrin-B2, there was an initial drop in EphB2 protein within the lesion site at $1 \mathrm{~d}(\sim 35 \%)$, which was followed by a rapid increase that reached $\sim 160 \%$ of uninjured levels by day 7 . At both 10 and $14 \mathrm{~d}$ after lesion, there was a significant increase in EphB2 of $>400 \%$ $(p<0.001)$ from normal levels (Fig. 3E). To determine whether there was activation of EphB2 at the different survival times, the phosphorylation state of EphB2 receptors was determined by probing the Western blots containing immunoprecipitated EphB2 with anti-phosphotyrosine antibody (Fig. 3D, bottom).

Quantification of phosphorylation levels for EphB2 ( $n=3$ per group) revealed a significant difference between survival times (one way ANOVA; $p<0.0002$ ). A low level of EphB2 phosphorylation was detected in the normal spinal cord tissue. Strikingly, at $3 \mathrm{~d}$ after injury, there was a

(Fig. 3A, bottom). Both antibodies produced comparable results at each postlesion survival time. Because the antibody against phosphorylated B-ephrins was more selective and sensitive in detecting phosphorylated ephrin-B2, these blots were used to quantify changes in the phosphorylation state of ephrin-B2 at the different postlesion times. Quantification of the phosphorylation levels of ephrin-B2 (Fig. 3C) demonstrated significant differences between groups (one-way ANOVA; $p<0.003$ ). These phosphorylation data indicated that there was a rapid and significant activation of ephrin-B2 at $1 \mathrm{~d}$ after lesion compared with control (339\%; $p<0.05)$, which additionally increased $3 \mathrm{~d}$ after lesion (435\%; $p<0.01)$. Phosphorylation levels remained elevated at $7 \mathrm{~d}(335 \%$; $p<0.05)$ before slowly decreasing. Because there were concomitant changes in both protein levels and phosphorylation states of ephrin-B2 at the different survival times, we developed a phosphorylation index to better compare the relative phosphorylation of ephrin-B2 at each lesion time with uninjured control levels. In uninjured control samples, the ratio of phosphorylated protein to the average total protein was set as one (100\% control phosphorylation divided by $100 \%$ total control protein). Similarly, the phosphorylation level (calculated as a percentage of control) for each postinjury time point was divided by the average total protein level (expressed as a percentage of control) for that time point. This method permitted us to approximate the fold change in ephrin-B2 phosphorylation and to compare the relative phosphorylation of total protein at each survival time with uninjured control levels. Based on this correction procedure for total protein, we still detected a significantly elevated phosphorylation state of ephrin-B2 at $1 \mathrm{~d}(9.88 \pm 0.76$ SEM fold increase above control levels; $p<0.001)$ and $3 \mathrm{~d}(4.81 \pm 0.43$ SEM fold increase; $p<0.001)$ after lesion. However, relative phosphorylation levels at $7 \mathrm{~d}(1.82 \pm 0.30 \mathrm{SEM}), 10 \mathrm{~d}(1.48 \pm$ transient increase $(1000 \% ; p<0.001)$ in the phosphorylation of EphB2 that was significantly different from control and all other postinjury time points (Fig. $3 F$ ). Because the levels of EphB2 protein at this survival time are only slightly elevated above (but not significantly different from) normal levels, these results indicate that a very high percentage of EphB2 receptors in the lesion site were activated at day 3 . However, this activation was rapidly terminated because there was only a 70\% elevation in EphB2 phosphorylation at day 7 (not significantly different from uninjured levels), although EphB2 protein levels at day 7 had significantly increased $150 \%$ above uninjured control levels. Similar low levels of EphB2 phosphorylation were detected at 10 and $14 \mathrm{~d}$ after lesion. Because there was a significant increase in EphB2 protein in the lesion site at 10 and $14 \mathrm{~d}(>400 \%)$, this indicates that a very low percentage of EphB2 receptors present on cells in the lesion cavity are activated at these longer survival times. These observations were confirmed with the phosphorylation index, which indicated that there was a significant increase in EphB2 phosphorylation above control levels only at $3 \mathrm{~d}$ after lesion $(7.42 \pm 1.44$ SEM fold increase; $p<0.001)$

\section{Histological evaluation of ephrin-B2 after injury}

We used double-label immunohistochemistry to determine which cell populations contributed to the changes seen in ephrin-B2 protein levels during the different stages of the injury response. In agreement with our observations that ephrin-B2 was expressed on astrocytes in the uninjured spinal cord (Fig. 1), astrocytes within the injured spinal cord also expressed ephrin-B2 at all postlesion survival times (Fig. 4). Double staining for ephrin-B2 and GFAP confirmed that all astrocytic processes along the lesion interface contained ephrin-B2 (Fig. 4A$E)$. At $3 \mathrm{~d}$ after injury, the lesion site was very large and 
hemorrhagic, and there was no well defined lesion interface (Fig. $4 A, B$ ). EphrinB2-positive astrocytes were loosely distributed within the injured region of the spinal cord. In this region, a few hypertrophic astrocytes possessed increased immunoreactivity for ephrin-B2, whereas the majority of cells maintained levels similar to uninjured controls. At the lesion interface, ephrin-B2-stained astrocytic processes in both white and gray matter still exhibited a preferential rostrocaudal orientation in horizontal sections (as observed in the uninjured spinal cord) and did not have processes oriented parallel to the lesion interface. By $7 \mathrm{~d}$ after injury, the lesion interface was more defined. All astrocytes were positive for ephrin-B2 (Fig. 4C), and there was an increased accumulation of ephrin-B2-GFAP-positive astrocytes along the margins of the lesion. These reactive astrocytes now possessed many processes preferentially oriented parallel to the lesion interface. On the basis of immunohistochemical specimens developed with the peroxidase reaction (see Materials and Methods), we were also able to detect a progressive increase in the intensity of ephrin-B2 immunoreactivity in hypertrophic astrocytes that now formed a more compact barrier around the lesion cavity at $7 \mathrm{~d}$ compared with $3 \mathrm{~d}$ after injury.

At $14 \mathrm{~d}$ after injury, astrocytes expressing ephrin-B2 encapsulated the lesion cavity and formed a characteristic glial scar rostral and caudal to the injury site (Fig. $4 D, E)$. Astrocytes in the area of the glial scar exhibited extensive ephrin-B2 immunoreactivity and possessed long slender processes that were now preferentially oriented parallel to the lesion surface. A comparison of ephrin-B2 staining intensity in astrocytes located proximal and distal to the injury indicated that astrocytes along the lesion interface exhibited very dense ephrin-B2 staining compared with astrocytes in the white and gray matter at more distal regions (Fig. $4 F$ ). Astrocytes distal to the lesion possessed a similar morphology to astrocytes in uninjured spinal cord, with processes directed in a rostrocaudal orientation in longitudinal tissue sections. In addition, ephrin-B2 immunoreactivity in individual astrocytes at the lesion interface was much stronger at $14 \mathrm{~d}$ compared with $3 \mathrm{~d}$ after injury (Fig. 4B,E). No other cell type upregulated ephrin-B2 protein in response to the spinal cord injury. These immunohistochemical observations correlate well with the biochemical data. The combined results suggest that the initial decrease in ephrin-B2 protein seen in the Western blots is attributable to hemorrhagic necrosis and edema during the first days of the acute injury response. During this time, there is considerable cell loss in the spinal cord regions adjacent to the lesion, although astrocytes in the injury zone still express ephrin-B2. By $3 \mathrm{~d}$ after

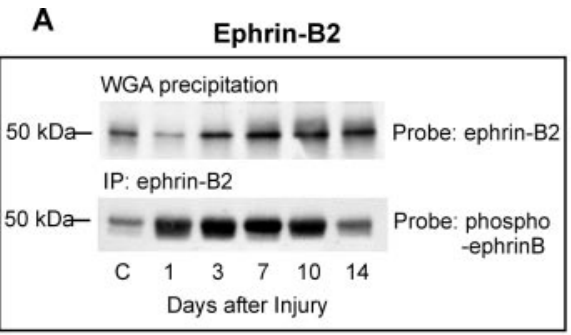

D EphB2
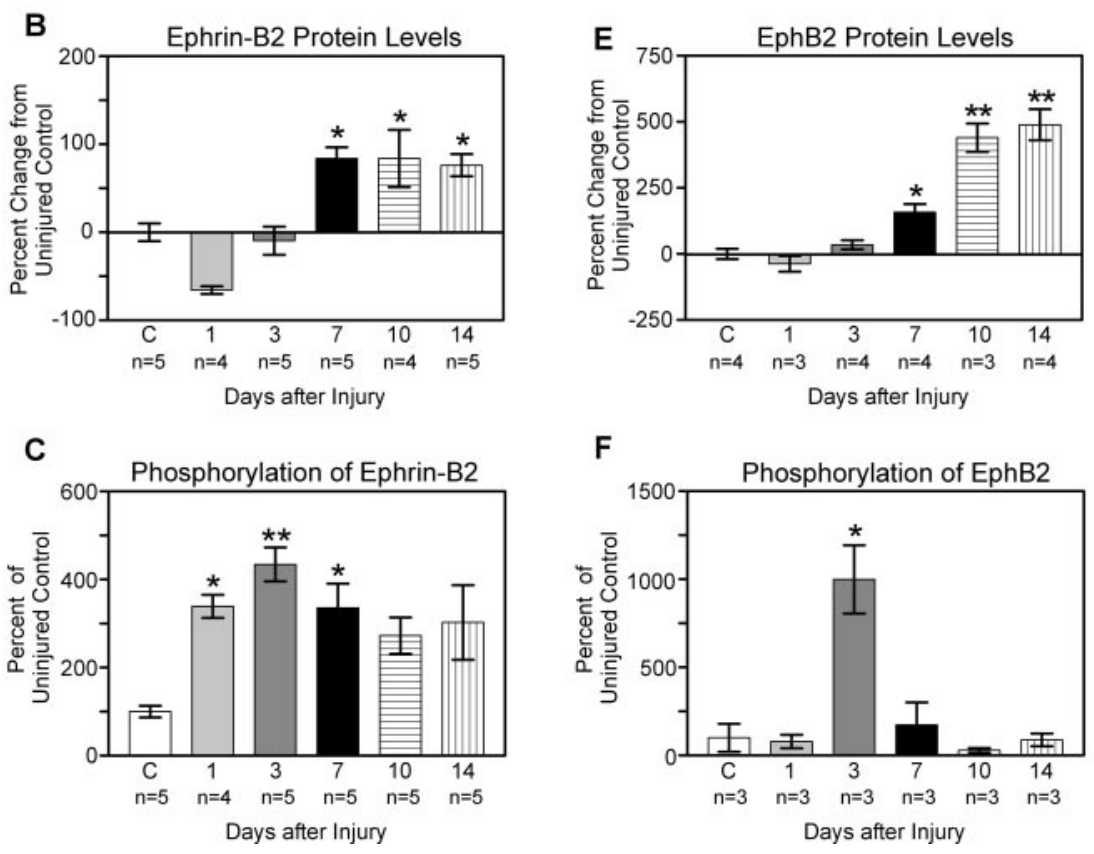

Figure 3. Western blots and quantification of protein and phosphorylation levels at progressive time points $(1,3,7,10$, and $14 \mathrm{~d}$ ) after complete 77 transections of the spinal cord. $A$, Representative Western blot illustrating temporal changes in ephrin-B2 protein and phosphorylation. Ephrin-B2 proteins were precipitated with WGA, and blots were probed with anti-ephrin-B2 (top). Ephrin-B2 protein was immunoprecipitated (IP) with anti-ephrin-B2, and resulting Western blots were probed with an antibody recognizing phosphorylated B-ephrins (bottom). B, Quantification of ephrin-B2 protein. At $1 \mathrm{~d}$ after lesion, there was a decrease in ephrin-B2 of $\sim 66 \%$ from control (C) levels. Ephrin-B2 protein quickly rebounded to near control levels by $3 \mathrm{~d}$ and exhibited a significant increase of $76-84 \%$ above uninjured levels from 7 to $14 \mathrm{~d}$ after lesion. Protein levels 7, 10, and $14 \mathrm{~d}$ after lesion were not significantly different from one another but were significantly different $\left({ }^{*}\right)$ from uninjured control $(p<0.05)$, from $1 \mathrm{~d}$ after lesion ( $p<0.001$ ), and $3 \mathrm{~d}$ after lesion ( $p<0.01$; Tukey's post hoc test). C, Quantification of ephrin-B2 phosphorylation. Low levels of ephrin-B2 phosphorylation were detected in uninjured tissue. At $1 \mathrm{~d}$ after lesion, there was a rapid and significant activation of ephrin-B2 compared with control (339\%; $p<0.05)$, which additionally increased $3 \mathrm{~d}$ after lesion $(435 \% ; p<0.01)$. Phosphorylation levels remained elevated at $7 \mathrm{~d}(335 \% ; p<0.05)$ before slowly decreasing. $D$, Representative Western blot illustrating temporal changes in EphB2 protein and phosphorylation. EphB2 protein was immunoprecipitated with anti-EphB2, and resulting Western blots were probed with anti-EphB2 (top). Activated EphB2 receptors were identified by immunoprecipitating EphB2 and probing the resulting Western blots with anti-phosphotyrosine (PTyr; bottom). E, Quantification of EphB2 protein. As for ephrin-B2, there was an initial drop in EphB2 protein at $1 \mathrm{~d}$, which was followed by an increase that reached $\sim 160 \%$ of uninjured levels by day 7 . At both 10 and $14 \mathrm{~d}$, there was a highly significant increase in EphB2 protein of $>400 \%$ from uninjured levels. Protein levels 10 and $14 \mathrm{~d}$ after lesion were significantly different $\left({ }^{* *}\right)$ from uninjured, $1,3(p<0.001)$, and 7 $(p<0.01)$ d. Protein levels $7 \mathrm{~d}$ after lesion were significantly different $(*)$ from levels $1 \mathrm{~d}$ after lesion $(p<0.05)$. F, Quantification of EphB2 phosphorylation. A low level of EphB2 phosphorylation was detected in uninjured spinal cord tissue. At $3 \mathrm{~d}$ after injury, there was a highly significant and transient increase $(1000 \% ; p<0.001)$ in EphB2 phosphorylation.

lesion, when ephrin-B2 protein levels are returning to normal levels, astrocytes are beginning to proliferate and upregulate production of ephrin-B2 protein. The marked increase in ephrin-B2 protein at the spinal cord injury site that was detected on the Western blots at 7-14 d after injury is consistent with the histological data indicating that there is both an increased density of ephrin-B2-expressing astrocytes along the spinal cord lesion interface and that individual astrocytes hypertrophy and upregulate ephrin-B2 as the glial scar matures. 

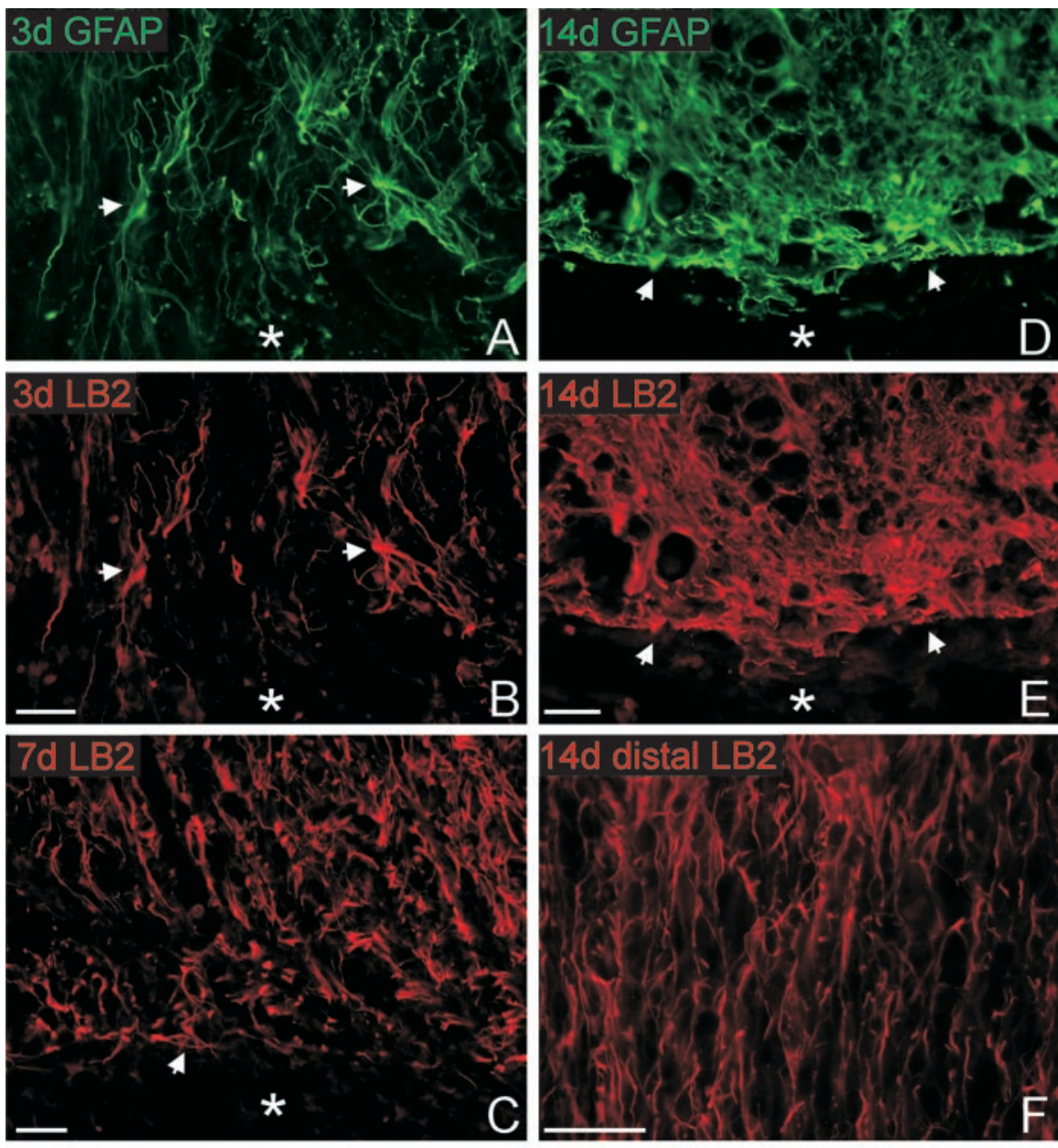

Figure 4. Reactive astrocytes at the lesion interface express ephrin-B2. Horizontal sections through lesioned tissue were double stained for GFAP ( $A, D$; green) and ephrin-B2 (LB2; $B, C, E, F$; red) to demonstrate colocalization within astrocytes. Rostral is oriented toward the top of the page, and the lesion cavity is marked with an asterisk in each panel. The injured tissue immediately rostral to the lesion is depicted in $A-E$. $A, B, A t 3$ d after injury, ephrin-B2-positive astrocytes were loosely distributed around the lesion area. A few hypertrophic astrocytes double stained for GFAP (arrows) had increased ephrin-B2 immunoreactivity. Astrocytic processes were disorganized and oriented radially toward the lesion but not parallel along the lesion surface. $C$, By $7 \mathrm{~d}$ after injury, many ephrin-B2-positive astrocytes had reoriented their processes parallel to the lesion interface (arrow).D, E, At $14 \mathrm{~d}$ after injury, astrocytes at the glial scar formed a dense cellular network with slender processes oriented parallel to the lesion surface. All astrocytes and astrocytic processes along the lesion surface possessed high levels of ephrin-B2 immunoreactivity compared with astrocytes in white matter several millimeters distal to the lesion site in the same tissue section ( $F$. Scale bars, $50 \mu \mathrm{m}$.

\section{Histological evaluation of EphB2 after injury}

Double-label immunohistochemistry was used to determine which cell populations expressed EphB2 protein during the different stages of the injury response. For this study, horizontal sections through the spinal cord lesion site were stained for EphB2 and fibronectin (as a marker for fibroblasts) at 3, 7, and $14 \mathrm{~d}$ after lesion. At $3 \mathrm{~d}$ after injury, a loose meshwork of EphB2-positive cells had infiltrated the lesion cavity (Fig. 5A). These cells were positive for fibronectin (Fig. 5B) and possessed an ovoid-shaped cell body with long, filamentous processes characteristic of fibroblasts. Moreover, these cells formed a contiguous stream that appeared to originate from the damaged meninges. By $7 \mathrm{~d}$ after injury, EphB2 immunostaining in the lesion cavity greatly increased because of enhanced staining in individual cells and a denser network of cells extending from the meningeal surface. This enhanced EphB2 staining continued for several millimeters along the meninges, rostral and caudal to the lesion. The density of the EphB2-fibronectin-positive cells continued to increase, and, by $14 \mathrm{~d}$, the lesion cavity was densely filled with EphB2positive fibroblasts (Fig. $5 C-F$ ). These fibroblasts were organized as continuous layers of cells that extended from the original meninges to cap the lesioned ends of the spinal cord. At $14 \mathrm{~d}$ after injury, fibroblasts located at the interface of the glial scar exhibited intense EphB2 immunoreactivity (Fig. 5C,E), whereas fibronectinstained cells within the center of the lesion cavity (Fig. 5D) were less immunoreactive for EphB2 (Fig. 5C). This observation suggests that there may be a downregulation of EphB2 in fibroblasts within regions of the lesion cavity that are not apposed to the glial scar. At all postlesion survival times analyzed, there was no apparent expression of EphB2 by any other cell types in the injury zone. Moreover, EphB2-positive cells were negative for markers for activated macrophages-microglia (OX42), astrocytes (GFAP), neurons (NeuN), and oligodendrocytes (APC). EphB2 immunostaining also was absent along the vascular bed.

To more completely characterize the initial interactions between ephrin-B2-expressing astrocytes and EphB2-expressing fibroblasts at $3 \mathrm{~d}$ after lesion, we double immunostained horizontal spinal cord tissue sections for fibronectin and ephrin-B2 or for GFAP and EphB2. In agreement with our biochemical data indicating bidirectional activation of ephrin-B2 and EphB2 at $3 \mathrm{~d}$, which requires cell-cell contact, ephrin-B2positive cells were interdigitated between fibronectin-positive fibroblasts (Fig. 6A-C). Likewise, EphB2-positive cell bodies and processes were intermingled among GFAPpositive astrocytes (Fig. $6 D-F$ ). Interestingly, some fibroblasts were in close proximity to ephrin-B2-positive astrocytes that possessed swollen processes, which appeared to be retracting (Fig. 6C). By day 7, astrocytes along the lesion surface had proliferated and upregulated ephrin-B2 expression. Moreover, their processes were oriented more parallel to the lesion surface. At this time, EphB2-positive fibroblasts also were more densely concentrated along this developing glial-fibrotic border and exhibited less intermingling with the astrocytes. By $14 \mathrm{~d}$ after lesion, EphB2-positive fibroblasts and ephrin-B2-positive astrocytes had clearly established exclusive territories along the lesion interface (Fig. 6G,H). This reduction of intermingling also was consistent with the biochemical data, indicating that ephrin-B2 and EphB2 phosphorylation levels at $14 \mathrm{~d}$ after injury were no longer significantly different from phosphorylation levels in the uninjured spinal cord.

\section{Discussion}

Cellular responses after spinal cord injury

Spinal cord injury leads to many cellular changes along the lesioned surface of the CNS (for review, see Berry et al., 1983; Eng et al., 1987; Reier and Houle, 1988; Schwab and Bartholdi, 1996). During the acute phase of injury ( $1-3 \mathrm{~d})$, there is disruption of the blood-brain barrier, neuronal death, degeneration of axons, reactive gliosis, and infiltration of immune cells and meningeal fibroblasts. During the subsequent subacute phase (3-14 d), as- 
trocytes proliferate and produce a network of interweaving processes that encapsulate the lesion and form a glial scar that restricts additional invasion of the CNS by meningeal cells. Astrocyte migration from the spinal cord parenchyma into the lesion cavity also is restricted (Imperato-Kalmar et al., 1997; Casella et al., 2002; Loy et al., 2002). During this time, astrocytes and meningeal fibroblasts secrete extracellular matrix (ECM) molecules and form a basal lamina along their interface (Abnet et al., 1991; Sievers et al., 1994). The basal lamina, astrocytic end feet, and tight junctions between the associated meningeal fibroblasts contribute to the reformed glial limitans and the restoration of the blood-brain barrier (for review, see Peters et al., 1976; Reier et al., 1986). Concomitant with these cellular changes along the glial-fibrotic scar, there is deposition of additional molecules at the scar that are inhibitory for axonal growth (Silver, 1994; McKeon et al., 1995, 1999; Fawcett and Asher, 1999; Fitch et al., 1999; Plant et al., 2001; Bradbury et al., 2002; Jones and Tuszynski, 2002; Jones et al., 2002; Liesi and Kauppila, 2002).

At present, it is unknown what molecular interactions between astrocytes and meningeal fibroblasts are responsible for initiating the cascade of cellular changes that leads to the formation of the glialfibrotic scar. It is likely that a combination of diffusible factors (growth factors and cytokines) and cell contact-mediated interactions are necessary for triggering signaling events that result in the formation of a restricted boundary between CNS astrocytes and invading meningeal fibroblasts. Here, we provide evidence that EphB receptors and B-ephrins participate in cell contact-mediated interactions that occur during the early stages of the spinal cord injury response. Histological data presented in this study demonstrate that ephrin-B2 is expressed by astrocytes and EphB2 is present on meningeal fibroblasts in the adult spinal cord. In response to spinal cord injury, ephrin-B2-immunoreactive astrocytes at the lesion and infiltrating meningeal fibroblasts bearing EphB2 undergo a progression of morphological changes that result in the formation of mutually restrictive glial and meningeal terrains. Our biochemical results demonstrate transient activation of ephrin-B2 and EphB2 that temporally coincides with the initial invasion of meningeal fibroblasts into the lesion cavity. We propose that cell contact-mediated binding of ephrin-B2 to EphB2 receptors initiates bidirectional intracellular signaling cascades that inhibit intermixing of astrocytes and meningeal fibroblasts at the lesion interface.

\section{Ephrins and Eph receptors have multiple functions}

Eph receptors and ephrins are implicated in diverse biological functions, including axon guidance, vascular development, for-
EphB2
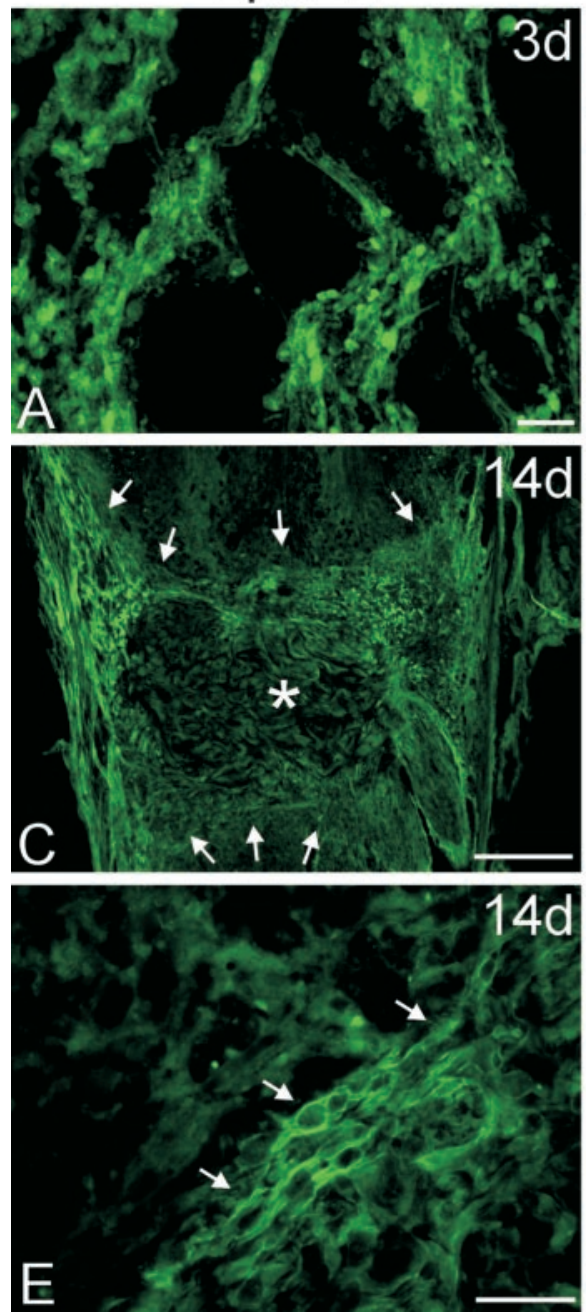

Figure 5. Immunohistochemistry for EphB2 after injury. Horizontal sections through the spinal cord lesion were double stained for EphB2 ( $A, C, E$; green) and fibronectin (FN; $B, D, F$; red) to detect fibroblasts in the lesion cavity at 3 and $14 \mathrm{~d}$ after injury. In all panels, rostral is oriented toward the top of the page. $A, B, \mathrm{At} 3 \mathrm{~d}$ after transection, there was generally weak EphB2 staining in the fibronectin $(B)$ infiltrated the lesion cavity along the lesion interface. These cells appeared to originate from the meninges. $B$ Inset, Higher magnification of a cell double stained for EphB2 and fibronectin. $C-F$, By $14 \mathrm{~d}$ after injury, the lesion cavity was filled entire lesion site. Asterisks mark the lesion epicenter, in which there is reduced EphB2 staining $(C)$, and arrows demarcate the -positive meningeal fibroblasts within the lesion. Arrows mark cells double stained for EphB2 and fibronectin at the lesion interface. Scale bars: $A, B, E, F, 50 \mu \mathrm{m} ; C, D, 500 \mu \mathrm{m}$. mation of tissue boundaries, cell migration, dendritic morphogenesis, and synaptogenesis (Dalva et al., 2000; Wilkinson, 2000; Ethell et al., 2001; Cooke and Moens, 2002; Murai et al., 2003; Penzes et al., 2003). Because both Eph receptors and ephrins are membrane-bound proteins, cell-mediated contact is required to initiate bidirectional signaling cascades, which regulate repulsive or adhesive interactions between cells (for review, see Holmberg et al., 2000; Klein, 2001; Wilkinson, 2001; Cowan and Henkemeyer, 2002; Holmberg and Frisen, 2002; Knoll and Drescher, 2002; Kullander and Klein, 2002). This balance between repulsion versus adhesion is partially mediated by differential activation of Rho versus Rac GTPase pathways, which regulate actin depolymerization (repulsion) and polymerization (adhesion), respectively (Shamah et al., 2001; Patel and Van Vactor, 2002). 

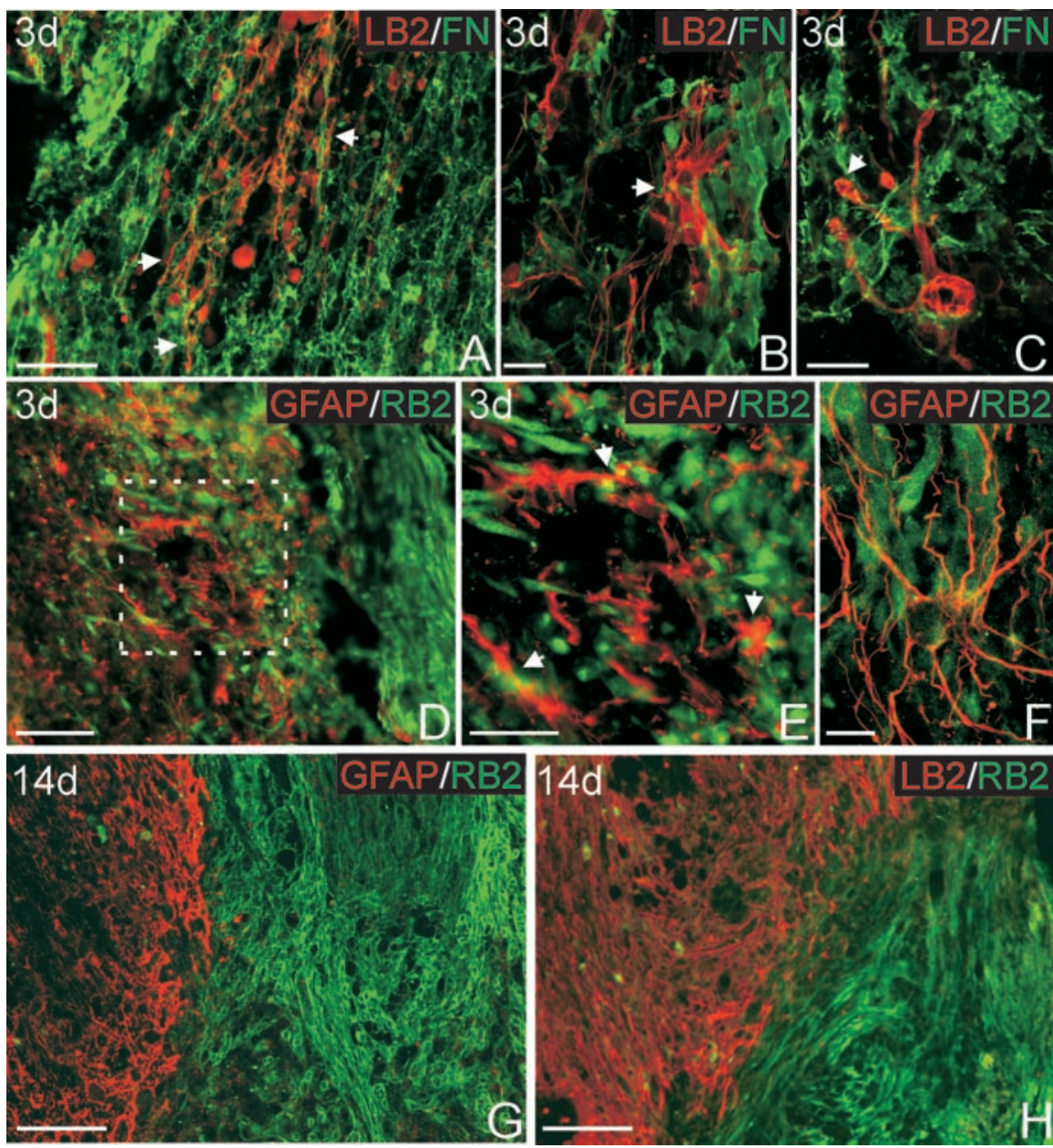

Figure 6. EphB2-positive fibroblasts and ephrin-B2-positive astrocytes intermingle $3 \mathrm{~d}$ after injury but form restricted domains along the spinal cord lesion interface $14 \mathrm{~d}$ after injury. $A-C$, Double staining for ephrin-B2 (LB2; red) to detect astrocytes and fibronectin (FN; green) to detect fibroblasts $3 \mathrm{~d}$ after injury. $A$, Ephrin-B2-positive astrocytic processes (arrows) intermingle with fibroblasts at the lesion site. $B$, Confocal image of an ephrin-B2-positive stellate astrocyte (arrow) in direct contact with fibroblasts. C, Confocal image of an ephrin-B2-positive astrocyte with swollen processes (arrow), potentially attributable to retraction after contacting fibroblasts. D, F, Double staining for GFAP (red) and EphB2 (RB2; green) to confirm astrocyte-fibroblast intermingling $3 \mathrm{~d}$ after injury. $E$, Higher magnification of lesion interface outlined in $D$, demonstrating direct contact between GFAP-positive astrocytic processes (arrows) and EphB2-positive fibroblasts. F, Confocal image demonstrating astrocytic processes interwoven among EphB2-positive cells. G, Lesion interface at $14 \mathrm{~d}$ after injury double stained for GFAP (red) and EphB2 (green). EphB2positive fibroblasts are strictly segregated from the spinal cord astrocytes at this survival time. $H$, Similar region of the spinal cord lesion double stained for ephrin-B2 (red) and EphB2 (green). Ephrin-B2-positive astrocytes and EphB2-positive fibroblasts are clearly segregated along the lesion border. Scale bars: $A, D, 100 \mu \mathrm{m} ; B, C, F, 20 \mu \mathrm{m} ; E, 50 \mu \mathrm{m} ; G, H, 200 \mu \mathrm{m}$.

Anderson, 1997; Wilkinson, 2001; Santiago and Erickson, 2002) and cell intermingling across rhombomere boundaries (Mellitzer et al., 1999; Xu et al., 1999; Wilkinson, 2000, 2001). Data presented in this study suggest that this developmental function of ephrins and Eph receptors is recapitulated after lesion in the adult CNS. Thus, we propose that segregation of astrocytes from meningeal fibroblasts at the glial-fibrotic scar occurs through mechanisms similar to those observed during rhombomere formation. For example, just as boundaries between rhombomere segments are initially blurred, similar to the astrocyte-fibroblast interface at $3 \mathrm{~d}$ after injury, over time, the boundaries between rhombomere compartments and the glialmeningeal border become sharp and distinct.

One unique feature of the glial-meningeal boundary is the formation of a basal lamina along the interface between the astrocytic processes and meningeal fibroblasts. It is possible that Eph-ephrin interactions contribute to this unique component of the glia limitans, because our histological data indicate that ephrinB2-expressing astrocytic end feet are juxtaposed to EphB2-expressing meningeal fibroblasts at the glia limitans in the normal adult spinal cord. In addition, our Western blots revealed that there is a baseline level of phosphorylation of EphB2 and ephrin-B2 in the uninjured adult spinal cord. Because Eph-ephrin signaling can modulate integrin-mediated cellular attachment to the extracellular matrix (Huynh-Do et al., 1999; Zou et al., 1999; Davy and Robbins, 2000; Miao et al., 2000; Huai and Drescher, 2001), Eph-ephrin signaling may participate in regulating the attachment of astrocytes and meningeal fibroblasts to the basal lamina that forms between these cells. Thus, Eph-ephrin interactions may contribute to maintaining

Both B-ephrins and EphB receptors possess cytoplasmic PDZ (postsynaptic density-95/Discs large/zona occludens-1)-binding domains that can regulate clustering of other molecules, such as postsynaptic NMDA receptors, in lipid microrafts on the cell surface (Hock et al., 1998; Hsueh and Sheng, 1998; Torres et al., 1998; Bruckner et al., 1999; Buchert et al., 1999; Kalo and Pasquale, 1999; Lin et al., 1999; Lu et al., 2001). Moreover, EphBephrin-B interactions may regulate cell attachment to the ECM by modulating integrin receptor signaling (Huynh-Do et al., 1999; Zou et al., 1999; Davy and Robbins, 2000; Miao et al., 2000; Huai and Drescher, 2001). Reverse signaling via the PDZ-binding domain of B-ephrins also can modulate cellular responses to chemokines by inhibiting receptor signaling through heterotrimeric G-proteins (Lu et al., 2001).

One important developmental function of Eph-ephrins, particularly relevant to the present study, is to restrict neural crest cell migration (Gale et al., 1996; Krull et al., 1997; Wang and the unique structural appearance of the glia limitans in the uninjured CNS, as well as assist in reestablishing the glia limitans after spinal cord injury.

\section{Model for ephrin-B2 and EphB2 interactions in response to spinal cord injury}

The present data suggest that ephrin-B2 and EphB2 participate in cell contact-mediated signaling that occurs between astrocytes and meningeal fibroblasts at the spinal cord lesion interface (Fig. 7). During the initial period after injury (1-3 d), our Western blot studies demonstrate a transient decrease in EphB2 and ephrin-B2 protein, likely attributable to tissue necrosis (Reier et al., 1983; Schwab and Bartholdi, 1996; Kuhn and Wrathall, 1998; Fawcett and Asher, 1999). The immunohistochemical data indicate that ephrin-B2-positive astrocytes are loosely distributed at the lesion, with their processes oriented perpendicular to the lesion cavity. Similarly, a disorganized network of EphB2-positive 
fibroblasts, which appear to originate from the meninges, is now present in the lesion cavity. Moreover, these two cell types intermingle along an ill-defined boundary at the lesion interface. Because ephrin-B2 and EphB2 are highly phosphorylated during this period of cell intermixing, we hypothesize that, at $3 \mathrm{~d}$ after lesion, cell-cell contact between EphB2-bearing fibroblasts migrating into the lesion cavity and ephrin-B2-expressing astrocytes at the edges of the lesion results in phosphorylation of both ephrin-B2 and EphB2 (Fig. $7 A$ ). This leads to activation of intracellular signaling pathways that trigger actin depolymerization and cell repulsion. Although our data strongly implicate direct astrocyte-fibroblast contact as the primary mechanism responsible for ephrin-B2 and EphB2 phosphorylation, we cannot completely eliminate the possibility that other ephrins and Eph receptors may partly contribute to this response. For example, some axons probably express EphB receptors or B-ephrins, and EphB4 may be expressed on blood vessels during injury-induced angiogenesis. There also is evidence that EphB3 is upregulated after contusive spinal cord injury (Miranda et al., 1999).

By $7 \mathrm{~d}$ after injury, there is increased expression of ephrin-B2 and EphB2 by astrocytes and meningeal fibroblasts that have now established more restricted cellular domains containing dense networks of interweaving processes. Along this interface, astrocytic processes are reoriented parallel to apposing layers of meningeal fibroblasts (Fig. $7 B$ ). Our histological results indicate that ephrin-B2-expressing astrocytes possess swollen processes during the period of ephrin-B2 activation. This suggests that contact-dependent repulsive interactions likely participate in regulating the reorientation of cells and cellular processes along the glial-fibrotic scar between 3 and $7 \mathrm{~d}$ after injury (Fig. $7 B$ ). Although a high level of phosphorylated ephrin-B2 is present at $7 \mathrm{~d}$ after injury, this phosphorylation level is not significantly different from control values when corrected for the increase in ephrin-B2 protein present in the glial scar at this time. Thus, our biochemical data indicate that there is a significant decrease in activation of both ephrin-B2 and EphB2 between 3 and $7 \mathrm{~d}$ after lesion, which coincides with the time that basal lamina components are deposited along the glial-meningeal interface. These results suggest that astrocytes and fibroblasts are initially repelled via cell contact-mediated Eph-ephrin signaling, but the continued segregation into restricted domains is probably maintained via the production of an intervening basal lamina.

By $14 \mathrm{~d}$ after injury, there is strict segregation of ephrin-B2-

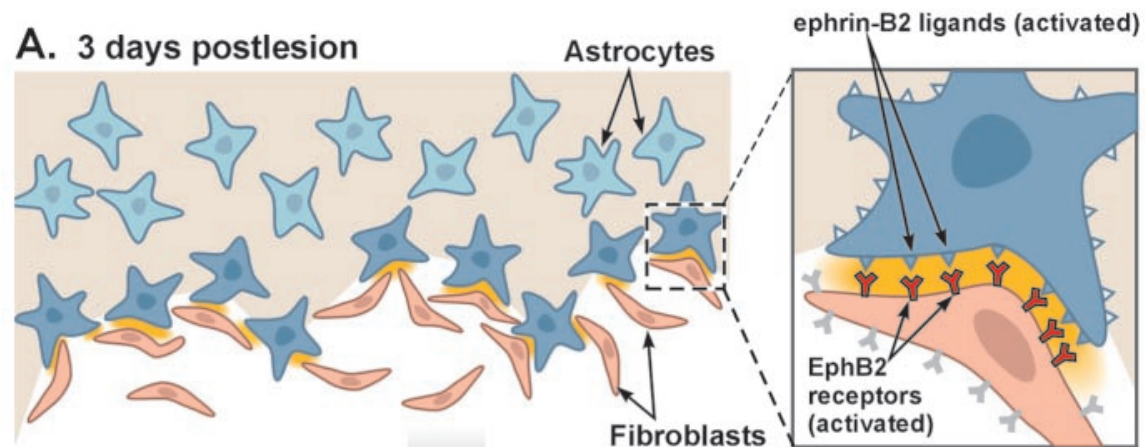

\section{B. 7 days postlesion}
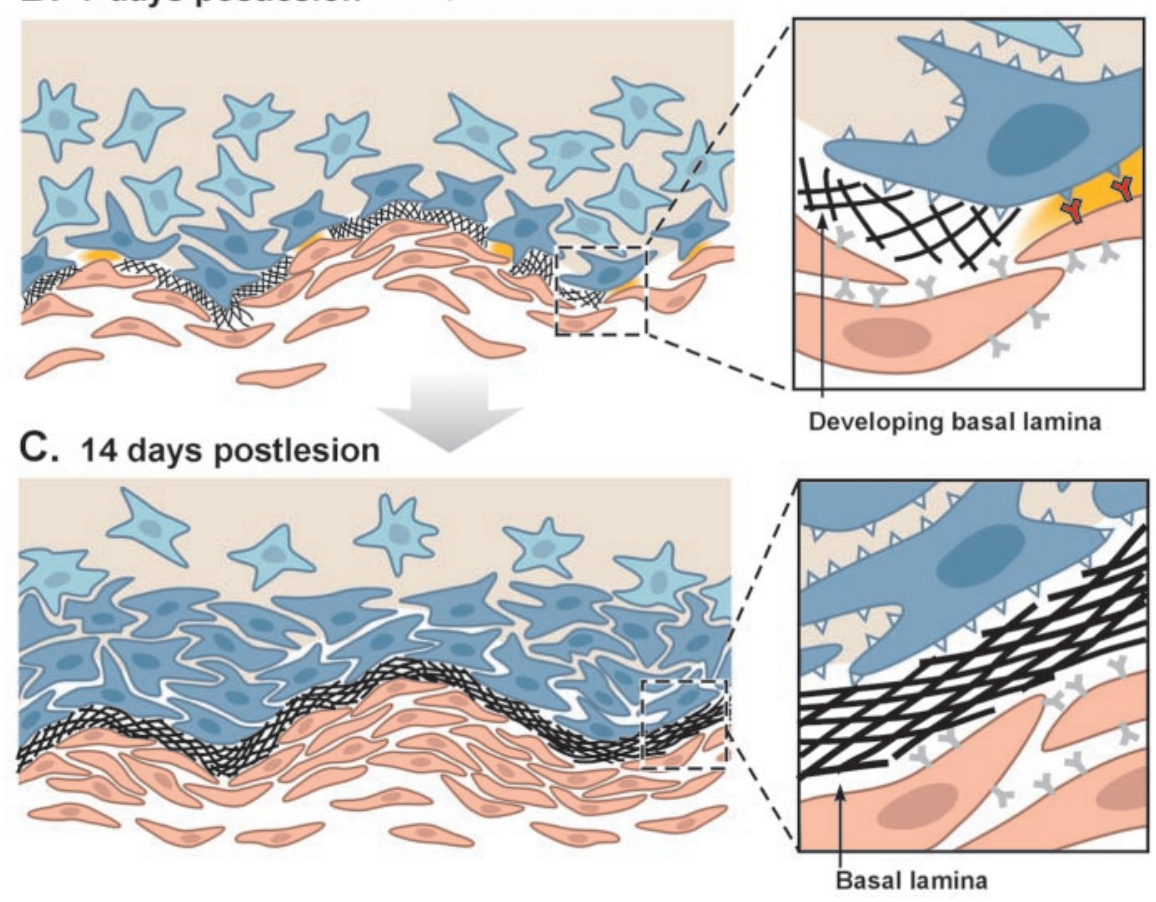

Figure 7. Schematic model for temporal interactions between reactive astrocytes and meningeal fibroblasts along the surface of the lesioned spinal cord. $A$, Three days after lesion, meningeal fibroblasts migrating into the lesion cavity begin making contact with astrocytes (yellow glow) along the lesioned surface of the spinal cord. In response to direct cell contact (inset), ephrin-B2 ligands on the surface of astrocytes bind to EphB2 receptors on invading fibroblasts, resulting in the phosphorylation of the tyrosine kinase domain on EphB2 (red receptors) and phosphorylation of conserved tyrosine residues on the cytoplasmic domain of ephrin-B2 (blue triangles). Receptor-ligand phosphorylation results in the initiation of bidirectional intracellular signaling cascades within the meningeal fibroblasts and reactive astrocytes. We propose that stimulation of EphB2 on the meningeal fibroblasts activates the Rho-GTPase pathway, producing local actin depolymerization that prevents additional infiltration of the fibroblasts into the spinal cord parenchyma. Activation of additional bidirectional signaling cascades in astrocytes and fibroblasts may initiate gene transcription for the deposition of ECM components by both cell types along their interface. $B$, Seven days after lesion, ECM components secreted by reactive astrocytes and meningeal fibroblasts form a basal lamina along areas of previous glial-meningeal contact. The deposition of this ECM prevents additional contact between ephrin-B2 and EphB2, resulting in a decrease in the endogenous phosphorylation and activation of EphB2 receptors on meningeal fibroblasts and ephrin-B2 on astrocytes. This decreased activation of the Eph-ephrin pathways may result in enhanced signaling through integrin receptor binding to the ECM components in the basal lamina, stabilizing the glial-meningeal boundary. C, Fourteen days after lesion. By this time, a basal lamina has completely formed along the glial-meningeal interface, and signaling between ephrin-B2 and EphB2 is terminated. Integrin-mediated binding of astrocytes and meningeal fibroblasts to the basal lamina now maintains the integrity of the glial-meningeal boundary.

expressing astrocytes from EphB2-positive meningeal fibroblasts (Fig. 7C), along with a several-fold increase in ephrin-B2 and EphB2 protein. These data are consistent with previous studies showing that the glial-fibrotic scar is fully developed at this time (Schwab and Bartholdi, 1996). Our biochemical data confirm that EphB2 and ephrin-B2 phosphorylation is not significantly different from uninjured control levels. By this time, a basal lam- 
ina is more fully developed between the astrocytes and fibroblasts, and signaling via interactions between integrin receptors and ECM components in the basal lamina may now help stabilize the glial limitans along the astrocyte-meningeal fibroblast interface.

The present observations provide the first evidence that interactions between B-class ephrins and EphB receptors participate in regulating cellular responses to injuries in the adult mammalian CNS. On the basis of our combined biochemical data and histological observations, we hypothesize that cell contactmediated bidirectional signaling between ephrin-B2-expressing astrocytes and EphB2-bearing meningeal fibroblasts initiate intracellular signaling cascades that are essential for regulating astrocyte and meningeal fibroblast segregation and glial-fibrotic scar formation after spinal cord injury. Future studies will be necessary to identify specific intracellular signaling pathways activated in response to EphB2 and ephrin-B2 binding and to determine how they initiate morphological changes in meningeal fibroblasts and reactive astrocytes that lead to glial scar formation, the reformation of the glial limitans and associated basal lamina, and the reestablishment of the unique homeostatic environment of the CNS.

\section{References}

Abnet K, Fawcett JW, Dunnett SB (1991) Interactions between meningeal cells and astrocytes in vivo and in vitro. Brain Res Dev Brain Res 59:187-196.

Berry M, Maxwell WL, Logan A, Mathewson A, McConnell P, Ashhurst DE, Thomas GH (1983) Deposition of scar tissue in the central nervous system. Acta Neurochir (Wien) [Suppl] 32:31-53.

Bradbury EJ, Moon LD, Popat RJ, King VR, Bennett GS, Patel PN, Fawcett JW, McMahon SB (2002) Chondroitinase ABC promotes functional recovery after spinal cord injury. Nature 416:636-640.

Bruckner K, Pasquale EB, Klein R (1997) Tyrosine phosphorylation of transmembrane ligands for Eph receptors. Science 275:1640-1643.

Bruckner K, Pablo Labrador J, Scheiffele P, Herb A, Seeburg PH, Klein R (1999) EphrinB ligands recruit GRIP family PDZ adaptor proteins into raft membrane microdomains. Neuron 22:511-524.

Buchert M, Schneider S, Meskenaite V, Adams MT, Canaani E, Baechi T, Moelling K, Hovens CM (1999) The junction-associated protein AF-6 interacts and clusters with specific Eph receptor tyrosine kinases at specialized sites of cell-cell contact in the brain. J Cell Biol 144:361-371.

Casella GT, Marcillo A, Bunge MB, Wood PM (2002) New vascular tissue rapidly replaces neural parenchyma and vessels destroyed by a contusion injury to the rat spinal cord. Exp Neurol 173:63-76.

Cooke JE, Moens CB (2002) Boundary formation in the hindbrain: Eph only it were simple. Trends Neurosci 25:260-267.

Coumans JV, Lin TT, Dai HN, MacArthur L, McAtee M, Nash C, Bregman BS (2001) Axonal regeneration and functional recovery after complete spinal cord transection in rats by delayed treatment with transplants and neurotrophins. J Neurosci 21:9334-9344.

Cowan CA, Henkemeyer M (2002) Ephrins in reverse, park and drive. Trends Cell Biol 12:339-346.

Cramer KS, Karam SD, Bothwell M, Cerretti DP, Pasquale EB, Rubel EW (2002) Expression of EphB receptors and EphrinB ligands in the developing chick auditory brainstem. J Comp Neurol 452:51-64.

Dalva MB, Takasu MA, Lin MZ, Shamah SM, Hu L, Gale NW, Greenberg ME (2000) EphB receptors interact with NMDA receptors and regulate excitatory synapse formation. Cell 103:945-956.

Davis S, Gale NW, Aldrich TH, Maisonpierre PC, Lhotak V, Pawson T, Goldfarb M, Yancopoulos GD (1994) Ligands for EPH-related receptor tyrosine kinases that require membrane attachment or clustering for activity. Science 266:816-819.

Davy A, Robbins SM (2000) Ephrin-A5 modulates cell adhesion and morphology in an integrin-dependent manner. EMBO J 19:5396-5405.

Eng LF, Reier PJ, Houle JD (1987) Astrocyte activation and fibrous gliosis: glial fibrillary acidic protein immunostaining of astrocytes following intraspinal cord grafting of fetal CNS tissue. Prog Brain Res 71:439-455.

Ethell IM, Irie F, Kalo MS, Couchman JR, Pasquale EB, Yamaguchi Y (2001)
EphB/syndecan-2 signaling in dendritic spine morphogenesis. Neuron 31:1001-1013.

Fawcett JW, Asher RA (1999) The glial scar and central nervous system repair. Brain Res Bull 49:377-391.

Fitch MT, Doller C, Combs CK, Landreth GE, Silver J (1999) Cellular and molecular mechanisms of glial scarring and progressive cavitation: in vivo and in vitro analysis of inflammation-induced secondary injury after CNS trauma. J Neurosci 19:8182-8198.

Flanagan JG, Vanderhaeghen P (1998) The ephrins and Eph receptors in neural development. Annu Rev Neurosci 21:309-345.

Gale NW, Holland SJ, Valenzuela DM, Flenniken A, Pan L, Ryan TE, Henkemeyer M, Strebhardt K, Hirai H, Wilkinson DG, Pawson T, Davis S, Yancopoulos GD (1996) Eph receptors and ligands comprise two major specificity subclasses and are reciprocally compartmentalized during embryogenesis. Neuron 17:9-19.

Gerety SS, Wang HU, Chen ZF, Anderson DJ (1999) Symmetrical mutant phenotypes of the receptor EphB4 and its specific transmembrane ligand ephrin-B2 in cardiovascular development. Mol Cell 4:403-414.

Hock B, Bohme B, Karn T, Yamamoto T, Kaibuchi K, Holtrich U, Holland S, Pawson T, Rubsamen-Waigmann H, Strebhardt K (1998) PDZdomain-mediated interaction of the Eph-related receptor tyrosine kinase EphB3 and the ras-binding protein AF6 depends on the kinase activity of the receptor. Proc Natl Acad Sci USA 95:9779-9784.

Holland SJ, Gale NW, Mbamalu G, Yancopoulos GD, Henkemeyer M, Pawson T (1996) Bidirectional signaling through the EPH-family receptor Nuk and its transmembrane ligands. Nature 383:722-725.

Holmberg J, Frisen J (2002) Ephrins are not only unattractive. Trends Neurosci 25:239-243.

Holmberg J, Clarke DL, Frisen J (2000) Regulation of repulsion versus adhesion by different splice forms of an Eph receptor. Nature 408:203-206.

Hsueh YP, Sheng M (1998) Eph receptors, ephrins, and PDZs gather in neuronal synapses. Neuron 21:1227-1229.

Huai J, Drescher U (2001) An ephrin-A-dependent signaling pathway controls integrin function and is linked to the tyrosine phosphorylation of a 120-kDa protein. J Biol Chem 276:6689-6694.

Huynh-Do U, Stein E, Lane AA, Liu H, Cerretti DP, Daniel TO (1999) Surface densities of ephrin-B1 determine EphB1-coupled activation of cell attachment through alphavbeta3 and alpha5betal integrins. EMBO J 18:2165-2173.

Imperato-Kalmar EL, McKinney RA, Schnell L, Rubin BP, Schwab ME (1997) Local changes in vascular architecture following partial spinal cord lesion in the rat. Exp Neurol 145:322-328.

Janis LS, Cassidy RM, Kromer LF (1999) Ephrin-A binding and EphA receptor expression delineate the matrix compartment of the striatum. J Neurosci 19:4962-4971.

Jones LL, Tuszynski MH (2002) Spinal cord injury elicits expression of keratan sulfate proteoglycans by macrophages, reactive microglia, and oligodendrocyte progenitors. J Neurosci 22:4611-4624.

Jones LL, Yamaguchi Y, Stallcup WB, Tuszynski MH (2002) NG2 is a major chondroitin sulfate proteoglycan produced after spinal cord injury and is expressed by macrophages and oligodendrocyte progenitors. J Neurosci 22:2792-2803.

Kalo MS, Pasquale EB (1999) Signal transfer by Eph receptors. Cell Tissue Res 298:1-9.

Kalo MS, Yu HH, Pasquale EB (2001) In vivo tyrosine phosphorylation sites of activated ephrin-B1 and EphB2 from neural tissue. J Biol Chem 276:38940-38948.

Karam SD, Burrows RC, Logan C, Koblar S, Pasquale EB, Bothwell M (2000) Eph receptors and ephrins in the developing chick cerebellum: relationship to sagittal patterning and granule cell migration. J Neurosci 20:6488-6500.

Klein R (2001) Excitatory Eph receptors and adhesive ephrin ligands. Curr Opin Cell Biol 13:196-203.

Knoll B, Drescher U (2002) Ephrin-As as receptors in topographic projections. Trends Neurosci 25:145-149.

Koblar SA, Krull CE, Pasquale EB, McLennan R, Peale FD, Cerretti DP, Bothwell M (2000) Spinal motor axons and neural crest cells use different molecular guides for segmental migration through the rostral halfsomite. J Neurobiol 42:437-447.

Krull CE, Lansford R, Gale NW, Collazo A, Marcelle C, Yancopoulos GD, Fraser SE, Bronner-Fraser M (1997) Interactions of Eph-related recep- 
tors and ligands confer rostrocaudal pattern to trunk neural crest migration. Curr Biol 7:571-580.

Kuhn PL, Wrathall JR (1998) A mouse model of graded contusive spinal cord injury. J Neurotrauma 15:125-140.

Kullander K, Klein R (2002) Mechanisms and functions of Eph and ephrin signaling. Nat Rev Mol Cell Biol 3:475-486.

Liesi P, Kauppila T (2002) Induction of type IV collagen and other basement-membrane-associated proteins after spinal cord injury of the adult rat may participate in formation of the glial scar. Exp Neurol 173:31-45.

Lin D, Gish GD, Songyang Z, Pawson T (1999) The carboxyl terminus of B class ephrins constitutes a PDZ domain binding motif. J Biol Chem 274:3726-3733.

Loy DN, Crawford CH, Darnall JB, Burke DA, Onifer SM, Whittemore SR (2002) Temporal progression of angiogenesis and basal lamina deposition after contusive spinal cord injury in the adult rat. J Comp Neurol 445:308-324.

Lu Q, Sun EE, Klein RS, Flanagan JG (2001) Ephrin-B reverse signaling is mediated by a novel PDZ-RGS protein and selectively inhibits $G$ proteincoupled chemoattraction. Cell 105:69-79.

McKeon RJ, Hoke A, Silver J (1995) Injury-induced proteoglycans inhibit the potential for laminin-mediated axon growth on astrocytic scars. Exp Neurol 136:32-43.

McKeon RJ, Jurynec MJ, Buck CR (1999) The chondroitin sulfate proteoglycans neurocan and phosphacan are expressed by reactive astrocytes in the chronic CNS glial scar. J Neurosci 19:10778-10788.

Mellitzer G, Xu Q, Wilkinson DG (1999) Eph receptors and ephrins restrict cell intermingling and communication. Nature 400:77-81.

Menzel P, Valencia F, Godement P, Dodelet VC, Pasquale EB (2001) Ephrin-A6, a new ligand for EphA receptors in the developing visual system. Dev Biol 230:74-88.

Miao H, Burnett E, Kinch M, Simon E, Wang B (2000) Activation of EphA2 kinase suppresses integrin function and causes focal-adhesion-kinase dephosphorylation. Nat Cell Biol 2:62-69.

Miranda JD, White LA, Marcillo AE, Willson CA, Jagid J, Whittemore SR (1999) Induction of EphB3 after spinal cord injury. Exp Neurol 156:218-222.

Murai KK, Nguyen LN, Irie F, Yamaguchi Y, Pasquale EB (2003) Control of hippocampal dendritic spine morphology through ephrin-A3/EphA4 signaling. Nat Neurosci 6:153-160.

Patel BN, Van Vactor DL (2002) Axon guidance: the cytoplasmic tail. Curr Opin Cell Biol 14:221-229.

Penzes P, Beeser A, Chernoff J, Schiller MR, Eipper BA, Mains RE, Huganir RL (2003) Rapid induction of dendritic spine morphogenesis by transsynaptic ephrinB-EphB receptor activation of the Rho-GEF kalirin. Neuron 37:263-274.

Peters A, Palay SL, Webster H (1976) In: The fine structure of the nervous system: the neurons and supporting cells. pp 231-263, 338-340. Philadelphia: Sanders.

Plant GW, Bates ML, Bunge MB (2001) Inhibitory proteoglycan immunoreactivity is higher at the caudal than the rostral Schwann cell grafttransected spinal cord interface. Mol Cell Neurosci 17:471-487.

Reier PJ, Houle JD (1988) The glial scar: its bearing on axonal elongation and transplantation approaches to CNS repair. Adv Neurol 47:87-138.

Reier PJ, Stensaas LJ, Guth L (1983) The astrocytic scar as an impediment to regeneration in the central nervous system. In: Spinal cord reconstruction (Kao CC, Bunge RP, Reier PJ, eds), pp 163-195. New York: Raven.

Reier PJ, Bregman BS, Wujek JR (1986) Intraspinal transplantation of embryonic spinal cord tissue in neonatal and adult rats. J Comp Neurol 247:275-296.

Sajjadi FG, Pasquale EB (1993) Five novel avian Eph-related tyrosine kinases are differentially expressed. Oncogene 8:1807-1813.

Santiago A, Erickson CA (2002) Ephrin-B ligands play a dual role in the control of neural crest cell migration. Development 129:3621-3632.

Schwab ME, Bartholdi D (1996) Degeneration and regeneration of axons in the lesioned spinal cord. Physiol Rev 76:319-370.

Shamah SM, Lin MZ, Goldberg JL, Estrach S, Sahin M, Hu L, Bazalakova M, Neve RL, Corfas G, Debant A, Greenberg ME (2001) EphA receptors regulate growth cone dynamics through the novel guanine nucleotide exchange factor ephexin. Cell 105:233-244.

Sievers J, Pehlemann FW, Gude S, Berry M (1994) Meningeal cells organize the superficial glia limitans of the cerebellum and produce components of both the interstitial matrix and the basement membrane. J Neurocytol 23:135-149.

Silver J (1994) Inhibitory molecules in development and regeneration. J Neurol 242:S22-S24.

Soans C, Holash JA, Pavlova Y, Pasquale EB (1996) Developmental expression and distinctive tyrosine phosphorylation of the Eph-related receptor tyrosine kinase Cek9. J Cell Biol 135:781-795.

Stein E, Lane AA, Cerretti DP, Schoecklmann HO, Schroff AD, Van Etten RL, Daniel TO (1998) Eph receptors discriminate specific ligand oligomers to determine alternative signaling complexes, attachment, and assembly responses. Genes Dev 12:667-678.

Torres R, Firestein BL, Dong H, Staudinger J, Olson EN, Huganir RL, Bredt DS, Gale NW, Yancopoulos GD (1998) PDZ proteins bind, cluster, and synaptically colocalize with Eph receptors and their ephrin ligands. Neuron 21:1453-1463.

Wang HU, Anderson DJ (1997) Eph family transmembrane ligands can mediate repulsive guidance of trunk neural crest migration and motor axon outgrowth. Neuron 18:383-396.

Wang HU, Chen ZF, Anderson DJ (1998) Molecular distinction and angiogenic interaction between embryonic arteries and veins revealed by ephrin-B2 and its receptor Eph-B4. Cell 93:741-753.

Wang YH, Bosy TZ, Yasuda RP, Grayson DR, Vicini S, Pizzorusso T, Wolfe BB (1995) Characterization of NMDA receptor subunit-specific antibodies: distribution of NR2A and NR2B receptor subunits in rat brain and ontogenic profile in the cerebellum. J Neurochem 65:176-183.

Wilkinson DG (2000) Eph receptors and ephrins: regulators of guidance and assembly. Int Rev Cytol 196:177-244.

Wilkinson DG (2001) Multiple roles of EPH receptors and ephrins in neural development. Nat Rev Neurosci 2:155-164.

Xu Q, Mellitzer G, Robinson V, Wilkinson DG (1999) In vivo cell sorting in complementary segmental domains mediated by Eph receptors and ephrins. Nature 399:267-271.

Zhou R (1998) The Eph family receptors and ligands. Pharmacol Ther 77:151-181.

Zou JX, Wang B, Kalo MS, Zisch AH, Pasquale EB, Ruoslahti E (1999) An Eph receptor regulates integrin activity through R-Ras. Proc Natl Acad Sci USA 96:13813-13818. 